\title{
The effect of different dietary fatty acids on lipoprotein metabolism: concentration-dependent effects of diets enriched in oleic, myristic, palmitic and stearic acids
}

\author{
Andrew M. Salter ${ }^{1 *}$, E. Heather Mangiapane ${ }^{1}$, Andrew J. Bennett ${ }^{2}$, Jennifer S. Bruce ${ }^{1}$, \\ Michael A. Billett ${ }^{2}$, Kay L. Anderton ${ }^{2}$, Christine B. Marenah ${ }^{3}$, Nigel Lawson ${ }^{3}$ and David A. White ${ }^{2}$ \\ ${ }^{1}$ Department of Applied Biochemistry and Food Science, University of Nottingham, Sutton Bonington Campus, \\ Loughborough LE12 SRD, UK \\ ${ }^{2}$ Department of Biochemistry, University of Nottingham Medical School, Nottingham NG7 2UH, UK \\ ${ }^{3}$ Department of Clinical Chemistry, City Hospital, Nottingham NG5 1PB, UK
}

(Received 4 November 1996 - Revised 14 July 1997 - Accepted 4 September 1997)

\begin{abstract}
While it is well established that the fatty acid composition of dietary fat is important in determining plasma lipoprotein cholesterol concentrations, the effects of changing the absolute quantities of the individual fatty acids are less clear. In the present study Golden Syrian hamsters were fed on isoenergetic, low cholesterol $(0.05 \mathrm{~g} / \mathrm{kg})$ diets containing 100,150 or $200 \mathrm{~g}$ added fat $/ \mathrm{kg}$. This consisted of triolein (TO) alone, or equal proportions of TO and either trimyristin (TM), tripalmitin (TP) or tristearin (TS). Each trial also included a control group fed on a diet containing $50 \mathrm{~g}$ TO $/ \mathrm{kg}$. As the mass of TO in the diet increased, plasma VLDL-cholesterol concentrations rose. The TM-rich diets produced a concentration-dependent increase in total plasma cholesterol which was a result of significant increases in both VLDL and HDL levels. The TP-rich diets increased plasma LDL- and HDL-cholesterol levels in a concentrationdependent manner. TS-containing diets did not increase the cholesterol content of any of the major lipoprotein fractions. Hepatic LDL-receptor mRNA concentrations were significantly decreased in animals fed on TP, while apolipoprotein B mRNA concentrations were significantly increased. Thus, on a low-cholesterol diet, increasing the absolute amount of dietary palmitic acid increases LDL-cholesterol more than either myristic or stearic acid. These effects on lipoprotein metabolism may be exerted through specific modulation of the expression of the LDL receptor and apolipoprotein $B$ genes.
\end{abstract}

Fatty acids: Lipoproteins: LDL receptor

It is generally accepted that plasma cholesterol concentration is influenced by the fatty acid composition of dietary fat. Thus, relative to monounsaturated and polyunsaturated fatty acids, dietary long-chain saturated fatty acids increase plasma cholesterol levels (Grundy \& Denke, 1990). However, not all saturated fatty acids have equivalent effects. Lauric (12:0), myristic (14:0) and palmitic (16:0) acids raise plasma cholesterol levels, though considerable controversy surrounds their relative potency (Denke \& Grundy, 1992; Derr et al. 1993; Sundram et al. 1994, Tholstrup et al. 1994b; Zock et al. 1994). By contrast, stearic acid does not appear to have such an effect and has been described as 'neutral' (Bonanome \& Grundy, 1988; Denke \& Grundy,
1991; Derr et al. 1993; Tholstrup et al. 1994a). We have recently shown that high fat $(200 \mathrm{~g} / \mathrm{kg})$, palmitic acid-rich diets increase plasma LDL-cholesterol concentrations in hamsters to a greater extent than those rich in myristic, stearic or oleic acids and that this is associated with decreased hepatic LDL receptor and increased apolipoprotein (Apo) B mRNA concentrations (Bennett et al. 1995a). The effect of changing the absolute amount of an individual fatty acid in the diet is less clear. Meta-analysis suggests that, depending on the fatty acid composition of the diet, increasing the amount of fat without altering the composition could have adverse effects on the lipoprotein profile (Mensink \& Katan, 1992). In the present study we have

\footnotetext{
Abbreviations: Apo, apolipoprotein; CETP, cholesteryl ester transfer protein; $\mathrm{dT}_{18}$, oligo deoxythymidine homopolymer (18 bases); HMG-CoA, hydroxymethylglutaryl-CoA; IDL, intermediate density lipoproteins; MTP, microsomal triacylglycerol transfer protein; TM, trimyristin; TO, triolein; TP, tripalmitin; TS, tristearin.
}

*Corresponding author: Dr A. M. Salter, fax + $44(0) 115951$ 6122, email Andrew.Salter@Nottingham.ac.uk 
extended our previous findings to look at the effects of increasing the concentration of individual fatty acids in the diet without major changes in the overall fatty acid composition.

\section{Materials and methods}

\section{Chemicals}

All reagents were of the highest purity commercially available and solvents were of analytical grade unless otherwise stated. Radioisotopes and Hybond $\mathrm{N}$ nylon membrane were obtained from Amersham International plc (Amersham, Bucks., UK). Bluescript SK and KS phagemids (hybrid type plasmids) and in vitro transcription kits were obtained from Stratagene Ltd (Cambridge, Cambs., UK). Restriction endonucleases, RNAse-free DNAse ( $E C$ 3.1.21.1), Taq DNA polymerase ( $E C$ 2.7.7.7) and bacteriophage $\mathrm{T} 4$ polynucleotide kinase were obtained from Boehringer Mannheim (Lewes, Sussex, UK). RPA II ribonuclease protection assay kits were obtained from AMS Biotechnology (Witney, Oxon., UK). Oligo deoxythymidine homopolymer (18 bases) $\left(\mathrm{dT}_{18}\right)$ and deoxynucleoside triphosphates were obtained from Pharmacia LKB (Milton Keynes, Bucks., UK). Polyadenylic acid and salmon testes DNA were obtained from Sigma Chemical Company (Poole, Dorset, UK). Bacteriophage T4 DNA ligase (EC 6.5.1.1) and reverse transcriptase (EC 2.7.7.49) were obtained from Gibco BRL (Paisley, Strathclyde, UK).

Maize starch, cellulose (Alphacel), salt mixture (Hegsted), vitamin mix, and cholesterol were obtained from ICN Flow (High Wycombe, Bucks., UK). Trimyristin (TM, $97 \%$ pure), tripalmitin (TP, 95\% pure) and triolein (TO, technical grade $65-70 \%$ pure) were obtained from Fluka (Glossop, Derby., UK). Tristearin (TS, 95\% pure) and L-cystine were obtained from Sigma Chemical Company.

\section{Animals and diets}

Four individual trials were conducted to test the effect of dietary oleic, myristic, palmitic and stearic acids respectively. For each trial thirty male Golden Syrian hamsters, 120-165 g (3-4 months old) were obtained from a colony housed at the Biomedical Services Unit, Queen's Medical Centre. This was originally derived from a colony established by Harlan Olac (Bicester, Oxon., UK). Animals were allowed 2 weeks to adapt to their new environment during which time they were allowed free access to food and tap water. They were fed on a standard rodent chow (Rat and Mouse Breeding Diet 422, Pilsbury, Northants, UK) which was provided initially in a pelleted form and then in the second week as ground meal. The room was lit from 06.00 to 18.00 hours, with temperature maintained at $21^{\circ}$ and humidity at $55 \pm 10 \%$.

Following this acclimatization period, hamsters were adapted to a semi-purified control diet (Table 1) over a further 2 weeks. This diet was mixed with ground chow in the proportion of $25: 75$ (diet: chow) and given for $2 \mathrm{~d}$. The proportion of control diet to chow was then increased to $50: 50$ for a further $2 \mathrm{~d}$ and finally to $80: 20$. It was found
Table 1. Composition of the diets ${ }^{*}+$

\begin{tabular}{lllll}
\hline Added fat $(\mathrm{g} / \mathrm{kg}) \ldots$ & 50 (control) & 100 & 150 & 200 \\
\hline Starch $(\mathrm{g} / \mathrm{kg})$ & 503 & 387 & 272 & 156 \\
Cellulose $(\mathrm{g} / \mathrm{kg})$ & 35 & 101 & 166 & 232
\end{tabular}

* Isoenergetic diets were formulated by replacing dietary carbohydrate with dietary fat and maintaining the energy density by increasing the cellulose (Alphacel, non-nutritive bulk) content. For details of the dietary fat, see Table 2 and p. 196

† All diets contained $(\mathrm{g} / \mathrm{kg})$ : casein 235 , L-cystine 3 , liver concentrate 1 , sucrose 106, linseed oll 5, Hegsted salt mixture 40, vitamin mix (ICN Flow, High Wycombe, Bucks., UK) 22.

that at this ratio the diet was well-tolerated by most animals. During the 2-week pre-trial period, food intake and animal weight were monitored every $2 \mathrm{~d}$. Any animal that lost more than $5 \%$ of its body weight in any $2 \mathrm{~d}$ period or more than $10 \%$ over the whole pre-trial period was excluded from the trial. Twenty-four of the remaining animals were then randomly allocated to one of four groups (six animals per group). These animals were transferred to appropriate test diets as indicated in Table 1. Each of the four trials contained a control group which continued to consume the low-fat $(50 \mathrm{~g} \mathrm{TO} / \mathrm{kg})$ control diet. The three test diets contained 100,150 or $200 \mathrm{~g}$ added fat $/ \mathrm{kg}$. This consisted of TO only (in the TO alone trial) or $500 \mathrm{~g}$ TO and $500 \mathrm{~g} \mathrm{TM}, \mathrm{TP}$ or TS $/ \mathrm{kg}$. Fats were added to the diet to replace the equivalent amount of energy as starch. Energy and nutrient density were maintained by increasing the cellulose content of the diet as appropriate (Table 1). The diets were mixed with rodent chow $(80: 20$, diet : chow) as in the pre-trial period and animals were fed on the diets for $28 \mathrm{~d}$. Food intake and animal weight were again monitored every $2 \mathrm{~d}$. Any animal that lost more than $20 \%$ of its initial body weight was removed from the trial. Faeces were collected between days 24 and 27 and frozen at $-30^{\circ}$ until further analysis. On day 28 , animals were fasted overnight and killed the following morning. They were anaesthetized using sodium pentabarbitone (Sagatal, $1 \mathrm{ml} / \mathrm{kg}$ ) and $3-4 \mathrm{ml}$ blood was collected by cardiac puncture. The liver was flushed with $10 \mathrm{ml}$ ice-cold $0.15 \mathrm{M}-\mathrm{NaCl}$, removed, immediately frozen in liquid $\mathrm{N}_{2}$ and stored at $-80^{\circ}$ until further analysis.

Table 2. Fatty acid composition of diets $(\mathrm{g} / 100 \mathrm{~g}$ total fatty acids recovered)

\begin{tabular}{lrrrrrrrr}
\hline Diet & SF & $14: 0$ & $16: 0$ & $18: 0$ & $16: 1$ & $18: 1$ & $18: 2$ & $18: 3$ \\
\hline 50 g TO & & 1.8 & 6.8 & 2.4 & 4.1 & 51.6 & 15.1 & 5.7 \\
(control) & & & & & & & & \\
100 gTO & & 2.0 & 5.9 & 2.0 & 4.4 & 55.2 & 13.1 & 3.8 \\
150 g TO & & 2.1 & 5.5 & 1.8 & 4.6 & 56.6 & 12.3 & 3.0 \\
200 gTO & & 2.1 & 5.3 & 1.8 & 4.7 & 57.4 & 11.9 & 2.6 \\
50 g TO & TM & 44.0 & 3.9 & 1.3 & & & & \\
50 g SF & TP & 1.1 & 45.6 & 1.3 & 2.3 & 29.2 & 8.5 & 3.2 \\
& TS & 1.0 & 4.5 & 42.5 & & & & \\
75 gTO & TM & 46.1 & 3.4 & 1.2 & & & & \\
75 g SF & TP & 1.1 & 47.0 & 1.2 & 2.4 & 29.4 & 7.5 & 2.5 \\
& TS & 1.0 & 4.1 & 44.2 & & & & \\
100 g TO & TM & 47.1 & 3.1 & 1.1 & & & & \\
100 g SF & TP & 1.2 & 47.7 & 1.1 & 2.4 & 29.5 & 7.0 & 2.0 \\
& TS & 1.1 & 3.8 & 45.1 & & & & \\
\hline
\end{tabular}

SF, saturated fat; TO, triolein; TM, trimyristin; TP, tripalmitin; TS, tristearin. 


\section{Fatty acid analysis of dietary fats and oils}

Chow, linseed oil, TO, TM, TP and TS $(50 \mathrm{mg})$ were extracted with $2 \mathrm{ml}$ chloroform-methanol $(1: 2, \mathrm{v} / \mathrm{v})$ and $200 \mu \mathrm{l}$ portions were taken for trans-methylation as previously described (Bennett et al. 1995a). Fatty acid methyl esters were analysed by GLC on a CP-Sil 88 capillary column $(50 \mathrm{~m} \times 0.25 \mathrm{~mm}$; Chromopak, London, UK) in a Perkin Elmer 8300 chromatograph (Perkin Elmer, Beaconsfield, Bucks., UK). These data were then used to calculate the fatty acid composition of the individual diets (Table 2).

\section{Separation of lipoproteins}

Lipoprotein fractions were separated from plasma (normally $1 \mathrm{ml}$ ) by sequential preparative ultracentrifugation in a Beckman Optima TLX benchtop ultracentrifuge as previously described (Bennett et al. 1995a). VLDL, intermediate-density lipoproteins (IDL), LDL and HDL were separated within density ranges of: $<1.006,1.006-1.02$, $1.02-1.06$ and $>1.06 \mathrm{~g} / \mathrm{ml}$ respectively. Cholesterol and triacylglycerol concentrations in plasma and lipoprotein fractions were determined on the Cobas Mira autoanalyser (Roche Diagnostics Ltd, Welwyn Garden City, Herts., UK) using the Olympus system reagent 5000-cholesterol and triacylglycerol (GPO Trinder) kits respectively. The interassay CV for the combined separation of lipoproteins and cholesterol analysis were assessed by taking six portions of pooled hamster plasma through the whole procedure. Table 3 indicates the results of this validation for the two fractions containing the most cholesterol; LDL and HDL. As can be seen the CV were 5.5 and $3.0 \%$ respectively and the mean recovery (i.e. the sum of all the individual fractions expressed as a percentage of the total plasma cholesterol) was $86 \%$. The loss in cholesterol during isolation was probably cumulative throughout the three ultracentrifugal spins. As such it was likely to have the largest effect on the two last fractions to be isolated, namely LDL and HDL. Indeed, strong, positive, linear correlations were seen between both LDL- and HDLcholesterol and percentage recovery $(P=0.014$ and 0.010 respectively) and accounted for 77 and $80 \%$ of the variation in the respective fractions. For this reason, all LDL and HDL values quoted in this paper were corrected to $100 \%$ recovery. Table 3 indicates that such correction improved the $\mathrm{CV}$ for both fractions.

Table 3. Reproducibility of separation of LDL and HDL fractions of plasma*

\begin{tabular}{lcll}
\hline & Mean & SD & CV \\
\hline LDL (mmol/l) & 0.39 & 0.021 & 5.3 \\
HDL (mmol/l) & 1.10 & 0.033 & 3.0 \\
Recovery (\%) & 86 & 4.2 & 4.9 \\
LDL (corrected) $\dagger$ & 0.45 & 0.011 & 2.3 \\
HDL (corrected) $\dagger$ & 1.28 & 0.031 & 2.4 \\
\hline
\end{tabular}

* For details of procedures, see pp. 196-197.

†Corrected to $100 \%$ recovery.
Determination of hepatic free and esterified cholesterol and faecal cholesterol

Hepatic free and esterified cholesterol and faecal cholesterol were separated and assayed as described previously (Bennett et al. 1995a). Data for hepatic free and esterified cholesterol are presented as $\mathrm{mg} / \mathrm{g}$ wet weight of liver. Data for faecal cholesterol are presented as $\mathrm{mg}$ produced per $3 \mathrm{~d}$.

\section{Isolation of hepatic total RNA and determination of $m R N A$ concentrations}

Total hepatic RNA was isolated by the guanidinium thiocyanate method essentially according to the method of Chomczynski \& Sacchi (1987). The mRNA concentrations for hepatic ApoB, hydroxymethylglutaryl-CoA (HMG-CoA) reductase (EC 1.1.1.34) and LDL-receptor genes were determined by a solution hybridization/RNAse protection assay as previously described (Bennett et al. $1995 a$ ). Results were corrected for variation in the mRNA content of total RNA samples by quantitation of polyA RNA using oligo $\mathrm{dT}_{18}$ hybridization (Harley, 1987). All mRNA values are expressed as attomol mRNA/ $\mu \mathrm{g}$ total RNA normalized to $20 \mathrm{ng}$ poly $\mathrm{A} / \mu \mathrm{g}$ total RNA. In a number of cases the amount of mRNA could not be accurately determined due to a 'smearing' of the bands on the gel. This is likely to be due to prior degradation of the RNA. The number of measurements made in each group is indicated in Table 6.

\section{Statistical analysis}

All statistical analyses were performed using the Genstat 5 for Windows software package (Lawes Agricultural Trust, Rothamstead Experimental Station, Herts., UK). An initial one-way ANOVA was performed on the control groups from each experiment. As no statistically significant differences were seen in any of the variables measured (see p. 198) further analysis was performed on the combined test groups from each experiment. Data were analysed by two-way ANOVA with type (TO, TM, TP or TS) and amount $(100,150,200 \mathrm{~g} / \mathrm{kg})$ of fat as factors. Tables indicate the residual degrees of freedom (df), standard error of differences of means (SED) and significances $(P)$ for type, amount and the interaction between type and amount of fat. The effect of amount of fat was further tested for linear and quadratic regression. The effect of type of fat was further partitioned to examine the effect of: (1) TO $v$. TM + TP + TS, (2) TS $v$. TM + TP and (3) TM $v$. TP. Thus, this allowed the examination of the effect of the monounsaturated fatty acid-rich fat compared with the saturated fatty acid-rich fats, the specific effects of the stearic acid-rich fat compared to the other saturated fats and any specific differences between the myristic and palmitic acid-rich fats. 
Results

\section{Fatty acid composition of diets}

Table 2 shows that within each trial the fatty acid composition of the diets containing 100,150 and $200 \mathrm{~g}$ $\mathrm{fat} / \mathrm{kg}$ was essentially constant. Diets containing $150 \mathrm{~g}$ fat $/ \mathrm{kg}$ or less were all well tolerated by the animals with only four out of a total of seventy-two failing to thrive (one each in the control and $150 \mathrm{~g} / \mathrm{kg}$ groups of the TM trial, one in the $150 \mathrm{~g} / \mathrm{kg}$ group of the TP trial and one in the $100 \mathrm{~g} / \mathrm{kg}$ group of the TS trial). However, the $200 \mathrm{~g}$ of fat $/ \mathrm{kg}$ diets were less well tolerated with two and three animals being withdrawn from the TP and TS groups respectively due to markedly reduced food intake and resultant loss of body weight. In general, animals tended to maintain, or slightly increase, their body weight with little difference in food intake across the dietary groups. However, animals on the highest dose of TP did show a significant reduction in food intake (control: 191 (SD 7.8) g v. $200 \mathrm{~g} / \mathrm{kg}: 150$ (SD 22.3) $\mathrm{g}$ food consumed over the whole trial, $P<0.05$ ).

\section{Comparison of control groups}

As indicated on p. 197, before pooling the results, a preliminary analysis of the control groups from each experiment was performed. Every variable measured was compared by one-way ANOVA. The only apparent significant differences were in percentage recovery of lipoproteins and uncorrected (for recovery) LDL and HDL. This was due to a lower mean recovery in the TP trial than in the other three. Further investigation indicated similar differences in recoveries for the test groups as well. However, when LDL and HDL were corrected for recovery, no significant difference between trials remained. Thus, for further analysis the test groups for each trial were included in a single two-way ANOVA.

\section{Comparison of test groups}

Table 4 shows plasma total cholesterol and lipoprotein cholesterol concentrations in each of the dietary test groups. Total plasma cholesterol was related to both the type and amount of dietary fat, but no interaction between

Table 4. Effect of different dietary fats on total plasma and lipoprotein cholesterol concentrations (mmol/l) in hamsters fed on diets containing 100,150 or $200 \mathrm{~g}$ fat $/ \mathrm{kg}$, consisting of triolein (TO) alone or equal proportions of TO and trimyristin (TM), tripalmitin (TP) or tristearin (TS)

(Mean values for six animals per group and combined means for each amount and type of fat)

\begin{tabular}{|c|c|c|c|c|c|c|c|c|c|}
\hline & \multirow[b]{2}{*}{ Type of fat $(T)$} & \multicolumn{3}{|c|}{ Amount of fat $(\mathrm{g} / \mathrm{kg})(\mathrm{A})$} & \multirow[b]{2}{*}{ Mean } & & \multicolumn{3}{|c|}{ ANOVA } \\
\hline & & 100 & 150 & 200 & & & df & SED & $P$ \\
\hline$\overline{\text { Total }}$ & $\begin{array}{l}\text { TO } \\
\text { TM } \\
\text { TP } \\
\text { TS } \\
\text { Mean }\end{array}$ & $\begin{array}{l}2.98 \\
2.95 \\
3.01 \\
3.30 \\
3.06\end{array}$ & $\begin{array}{l}3.17 \\
3.04 \\
3.81 \\
3.50 \\
3.38\end{array}$ & $\begin{array}{l}3.13 \\
3.86 \\
4.02 \\
3.53 \\
3.63\end{array}$ & $\begin{array}{l}3.09 \\
3.28 \\
3.61 \\
3.44 \\
3.36\end{array}$ & $\begin{array}{l}\mathrm{T} \\
\mathrm{A} \\
\mathrm{A} \times \mathrm{T}\end{array}$ & 53 & $\begin{array}{l}0.176 \\
0.153 \\
0.306\end{array}$ & $\begin{array}{l}0.032 \\
0.002 \\
0.153\end{array}$ \\
\hline VLDL & $\begin{array}{l}\text { TO } \\
\text { TM } \\
\text { TP } \\
\text { TS } \\
\text { Mean }\end{array}$ & $\begin{array}{l}0.53 \\
0.34 \\
0.36 \\
0.44 \\
0.42\end{array}$ & $\begin{array}{l}0.60 \\
0.48 \\
0.42 \\
0.37 \\
0.47\end{array}$ & $\begin{array}{l}0.75 \\
0.75 \\
0.47 \\
0.34 \\
0.58\end{array}$ & $\begin{array}{l}0.63 \\
0.52 \\
0.42 \\
0.38 \\
0.49\end{array}$ & $\begin{array}{l}T \\
A \\
A \times T\end{array}$ & 51 & $\begin{array}{l}0.069 \\
0.060 \\
0.120\end{array}$ & $\begin{array}{l}0.004 \\
0.031 \\
0.143\end{array}$ \\
\hline $\mathrm{IDL}^{*}$ & $\begin{array}{l}\text { TO } \\
\text { TM } \\
\text { TP } \\
\text { TS } \\
\text { Mean }\end{array}$ & $\begin{array}{c}0.92 \\
(0.09) \\
0.87 \\
(0.08) \\
0.85 \\
(0.07) \\
1.12 \\
(0.15) \\
0.94\end{array}$ & $\begin{array}{c}0.88 \\
(0.09) \\
0.89 \\
(0.08) \\
0.95 \\
(0.09) \\
1.10 \\
(0.13) \\
0.96\end{array}$ & $\begin{array}{c}0.99 \\
(0.10) \\
0.99 \\
(0.10) \\
1.07 \\
(0.12) \\
1.29 \\
(0.20) \\
1.08\end{array}$ & $\begin{array}{l}0.93 \\
0.92 \\
0.96 \\
1.17 \\
0.99\end{array}$ & $\begin{array}{l}T \\
A \\
A \times T\end{array}$ & 53 & $\begin{array}{l}0.052 \\
0.045 \\
0.091\end{array}$ & $\begin{array}{r}<0.001 \\
0.004 \\
0.899\end{array}$ \\
\hline LDL & $\begin{array}{l}\text { TO } \\
\text { TM } \\
\text { TP } \\
\text { TS } \\
\text { Mean }\end{array}$ & $\begin{array}{l}0.57 \\
0.61 \\
0.63 \\
0.78 \\
0.65\end{array}$ & $\begin{array}{l}0.56 \\
0.63 \\
0.74 \\
0.82 \\
0.69\end{array}$ & $\begin{array}{l}0.50 \\
0.71 \\
0.93 \\
0.83 \\
0.74\end{array}$ & $\begin{array}{l}0.54 \\
0.65 \\
0.77 \\
0.81 \\
0.69\end{array}$ & $\begin{array}{l}T \\
A \\
A \times T\end{array}$ & 53 & $\begin{array}{l}0.055 \\
0.048 \\
0.096\end{array}$ & $\begin{array}{r}<0.001 \\
0.151 \\
0.215\end{array}$ \\
\hline HDL & $\begin{array}{l}\text { TO } \\
\text { TM } \\
\text { TP } \\
\text { TS } \\
\text { Mean }\end{array}$ & $\begin{array}{l}1.74 \\
1.90 \\
1.83 \\
1.99 \\
1.87\end{array}$ & $\begin{array}{l}2.07 \\
1.85 \\
2.29 \\
2.12 \\
2.08\end{array}$ & $\begin{array}{l}1.70 \\
2.26 \\
2.38 \\
2 \cdot 10 \\
2 \cdot 11\end{array}$ & $\begin{array}{l}1.84 \\
2.00 \\
2.17 \\
2.07 \\
2.02\end{array}$ & $\begin{array}{l}A \\
T \\
A \times T\end{array}$ & 53 & $\begin{array}{l}0.104 \\
0.090 \\
0.180\end{array}$ & $\begin{array}{l}0.020 \\
0.018 \\
0.051\end{array}$ \\
\hline
\end{tabular}

IDL, intermediate density lipoprotein.

* Not normally distributed. Transformed data $\left(\log _{10} \times 100\right)$ are given with actual values in parentheses. 
Table 5. Effect of different dietary fats on plasma VLDL-triacylglycerol (TAG), hepatic free cholesterol (FC) and cholesteryl ester (CE) and faecal cholesterol (C) concentrations in hamsters fed on diets containing 100,150 or $200 \mathrm{~g}$ fat $/ \mathrm{kg}$, consisting of triolein (TO) alone or equal proportions of TO and trimyristin (TM), tripalmitin (TP) or tristearin (TS)

(Mean values for six animals per group and combined means for each amount and type of fat)

\begin{tabular}{|c|c|c|c|c|c|c|c|c|c|}
\hline & \multirow[b]{2}{*}{ Type of fat (T) } & \multicolumn{3}{|c|}{ Amount of fat $(\mathrm{g} / \mathrm{kg})(\mathrm{A})$} & \multirow[b]{2}{*}{ Mean } & & \multicolumn{3}{|c|}{ ANOVA } \\
\hline & & 100 & 150 & 200 & & & df & SED & $P$ \\
\hline VLDL-TAG* $(\mathrm{mmol} / \mathrm{l})$ & $\begin{array}{l}\text { TO } \\
\text { TM } \\
\text { TP } \\
\text { TS } \\
\text { Mean }\end{array}$ & $\begin{array}{c}1.97 \\
(0.97) \\
1.77 \\
(0.60) \\
1.89 \\
(0.82) \\
1.77 \\
(0.62) \\
1.85\end{array}$ & $\begin{array}{c}1.79 \\
(0.67) \\
1.81 \\
(0.68) \\
1.92 \\
(1.03) \\
1.53 \\
(0.38) \\
1.76\end{array}$ & $\begin{array}{c}1.84 \\
(0.72) \\
1.97 \\
(0.97) \\
1.78 \\
(0.67) \\
1.43 \\
(0.28) \\
1.76\end{array}$ & $\begin{array}{l}1.87 \\
1.85 \\
1.87 \\
1.58 \\
1.79\end{array}$ & $\begin{array}{l}\mathrm{T} \\
\mathrm{A} \\
\mathrm{A} \times \mathrm{T}\end{array}$ & 50 & $\begin{array}{l}0.058 \\
0.050 \\
0.100\end{array}$ & $\begin{array}{r}<0.001 \\
0.127 \\
0.016\end{array}$ \\
\hline Hepatic FC (mg/g) & $\begin{array}{l}\text { TO } \\
\text { TM } \\
\text { TP } \\
\text { TS } \\
\text { Mean }\end{array}$ & $\begin{array}{l}2.60 \\
2.31 \\
2.66 \\
2.65 \\
2.56\end{array}$ & $\begin{array}{l}2.66 \\
2.35 \\
2.86 \\
2.37 \\
2.56\end{array}$ & $\begin{array}{l}3.24 \\
2.58 \\
2.68 \\
2.71 \\
2.80\end{array}$ & $\begin{array}{l}2.83 \\
2.41 \\
2.73 \\
2.58 \\
2.64\end{array}$ & $\begin{array}{l}\mathrm{T} \\
\mathrm{A} \\
\mathrm{A} \times \mathrm{T}\end{array}$ & 53 & $\begin{array}{l}0.150 \\
0.130 \\
0.260\end{array}$ & $\begin{array}{l}0.039 \\
0.102 \\
0.373\end{array}$ \\
\hline Hepatic CE* $(\mathrm{mg} / \mathrm{g})$ & $\begin{array}{l}\text { TO } \\
\text { TM } \\
\text { TP } \\
\text { TS } \\
\text { Mean }\end{array}$ & $\begin{array}{c}2.72 \\
(6.67) \\
2.16 \\
(3.82) \\
2.21 \\
(2.59) \\
2.06 \\
(1.46) \\
2.29\end{array}$ & $\begin{array}{c}2.99 \\
(11.31) \\
2.63 \\
(4.58) \\
2.59 \\
(4.45) \\
2.03 \\
(1.36) \\
2.56\end{array}$ & $\begin{array}{c}3.03 \\
(11.32) \\
2.86 \\
(7.28) \\
2.47 \\
(4.27) \\
2.46 \\
(2.97) \\
2.70\end{array}$ & $\begin{array}{l}2.91 \\
2.55 \\
2.42 \\
2.19 \\
2.52\end{array}$ & $\begin{array}{l}\mathrm{T} \\
\mathrm{A} \\
\mathrm{A} \times \mathrm{T}\end{array}$ & 53 & $\begin{array}{l}0.127 \\
0.110 \\
0.220\end{array}$ & $\begin{array}{r}<0.001 \\
0.001 \\
0.444\end{array}$ \\
\hline Faecal C (mg/3d) & $\begin{array}{l}\text { TO } \\
\text { TM } \\
\text { TP } \\
\text { TS } \\
\text { Mean }\end{array}$ & $\begin{array}{l}3.72 \\
3.32 \\
4.54 \\
6.56 \\
4.53\end{array}$ & $\begin{array}{l}3.47 \\
3.31 \\
4.29 \\
9.24 \\
5.08\end{array}$ & $\begin{array}{l}3.44 \\
2.61 \\
4.98 \\
6.62 \\
4.41\end{array}$ & $\begin{array}{l}3.54 \\
3.08 \\
4.60 \\
7.47 \\
4.67\end{array}$ & $\begin{array}{l}\mathrm{T} \\
\mathrm{A} \\
\mathrm{A} \times \mathrm{T}\end{array}$ & 53 & $\begin{array}{l}0.346 \\
0.299 \\
0.599\end{array}$ & $\begin{array}{r}<0.001 \\
0.069 \\
0.002\end{array}$ \\
\hline
\end{tabular}

* Not normally distributed. Transformed data $\left(\log _{10} \times 100\right)$ are given with actual values in parentheses.

the two was seen. The largest effect of type of fat in our analysis was between $\mathrm{TO}$ and $\mathrm{TM}+\mathrm{TP}+\mathrm{TS}$ with the unsaturated fat group being significantly lower than the combined saturated fat group $(P=0.018)$. Plasma cholesterol increased linearly with amount of fat $(P<0.001)$.

Significant effects of type and amount of fat were also seen for VLDL- and IDL-cholesterol but there was no interaction. VLDL was significantly higher in the TO group compared with the combined $\mathrm{TM}+\mathrm{TP}+\mathrm{TS}$ group. There was an overall linear increase in VLDL with increasing amount of dietary fat $(P=0.01)$ but within the saturated fats there were significant differences in this regression between the TS group and the combined TM + TP groups $(P=0.016)$. While VLDL tended to fall with increasing amount of TS in the diet the opposite was true for $\mathrm{TM}+\mathrm{TP}$. IDL-cholesterol was found not to be normally distributed so statistical analysis was performed on transformed data $\left(\log _{10}(\mathrm{IDL} \times 100)\right)$. IDL-cholesterol concentrations increased with concentration of fat in the diet and the level was significantly higher in the TS group than in groups receiving the other saturated fatty acids $(P<0.001)$.

LDL-cholesterol concentration was significantly affected by the type of fat but not the amount, with significant differences being seen between TO $v$. TM $+\mathrm{TP}+\mathrm{TS}$ $(P<0.001), \mathrm{TS} v$. TM $+\mathrm{TP}(P=0.037)$ and $\mathrm{TM} v$. TP
$(P=0.034)$. The linear regression of amount of fat against LDL cholesterol almost attained significance $(P=0.054)$ and there was a significant difference in the linear regressions when TO was compared with the combined saturated fatty acids $(P=0.047)$.

An interactive effect of type and amount of fat was seen on HDL-cholesterol and when partitioned, quadratic regressions comparing TO with $\mathrm{TM}+\mathrm{TP}+\mathrm{TS}$ $(P=0.066)$ and TM with TP $(P=0.059)$ almost attained significance.

VLDL-triacylglycerol (Table 5) again was not normally distributed and was transformed as for IDL-cholesterol. A significant interaction between amount and type of fat was seen with significant differences in linear regression when TS was compared with TM + TP $(P=0.003)$ and TM and TP were compared $(P=0.036)$. In general, VLDLtriacylglycerol tended to decrease with increasing amounts of TS.

Hepatic free and esterified cholesterol were both influenced by the type of fat in the diet with the highest values in the TO group and lowest in the TS group. Hepatic cholesterol ester was again log-transformed. While no effect of amount of fat was seen on free cholesterol, the esterified form showed a strong linear relationship with the amount of fat $(P<0.001)$. No significant interactions between amount and type of fat were seen. There was a 
Table 6. Effect of different dietary fats on hepatic apolipoprotein B (ApoB), hydroxymethylglutaryl-CoA (HMG-CoA) reductase and LDL-receptor mRNA concentrations in hamsters fed on diets containing 100,150 or $200 \mathrm{~g}$ fat $/ \mathrm{kg}$, consisting of triolein (TO) alone or equal proportions of TO and trimyristin (TM), tripalmitin (TP) or tristearin (TS)

(Values are presented as mean attomol/ $\mu \mathrm{g}$ RNA normalized to $20 \mathrm{ng}$ polyA/ $\mu \mathrm{g}$ total RNA)

\begin{tabular}{|c|c|c|c|c|c|c|c|c|c|}
\hline & \multirow[b]{2}{*}{ Type of fat $(T)$} & \multicolumn{3}{|c|}{ Amount of fat $(\mathrm{g} / \mathrm{kg})(\mathrm{A})$} & \multirow[b]{2}{*}{ Mean } & & \multicolumn{3}{|c|}{ ANOVA } \\
\hline & & 100 & 150 & 200 & & & df & SED & $P$ \\
\hline$n$ & $\begin{array}{l}\text { TO } \\
\text { TM } \\
\text { TP } \\
\text { TS }\end{array}$ & $\begin{array}{l}5 \\
6 \\
5 \\
4\end{array}$ & $\begin{array}{l}5 \\
4^{*} \\
5 \\
5\end{array}$ & $\begin{array}{l}4^{\star} \\
4 \\
4 \\
2\end{array}$ & & & & & \\
\hline ApoB & $\begin{array}{l}\text { TO } \\
\text { TM } \\
\text { TP } \\
\text { TS } \\
\text { Mean }\end{array}$ & $\begin{array}{l}83 \\
69 \\
89 \\
66 \\
77\end{array}$ & $\begin{array}{l}83 \\
57 \\
88 \\
69 \\
74\end{array}$ & $\begin{array}{r}83 \\
66 \\
123 \\
76 \\
87\end{array}$ & $\begin{array}{r}83 \\
64 \\
100 \\
71 \\
79\end{array}$ & $\begin{array}{l}T \\
A \\
A \times T\end{array}$ & 39 & $\begin{array}{r}7.5 \\
6.5 \\
13.0\end{array}$ & $\begin{array}{r}<0.001 \\
0.139 \\
0.364\end{array}$ \\
\hline HMG-CoA reductase & $\begin{array}{l}\text { TO } \\
\text { TM } \\
\text { TP } \\
\text { TS } \\
\text { Mean }\end{array}$ & $\begin{array}{l}1.00 \\
1.17 \\
1.26 \\
1.22 \\
1.16\end{array}$ & $\begin{array}{l}1.36 \\
1.24 \\
1.03 \\
1.31 \\
1.23\end{array}$ & $\begin{array}{l}1.27 \\
1.07 \\
0.98 \\
1.34 \\
1.17\end{array}$ & $\begin{array}{l}1.21 \\
1.16 \\
1.09 \\
1.29 \\
1.19\end{array}$ & $\begin{array}{l}\mathrm{T} \\
\mathrm{A} \\
\mathrm{A} \times \mathrm{T}\end{array}$ & 41 & $\begin{array}{l}0.10 \\
0.08 \\
0.17\end{array}$ & $\begin{array}{l}0.214 \\
0.634 \\
0.206\end{array}$ \\
\hline LDL receptor & $\begin{array}{l}\text { TO } \\
\text { TM } \\
\text { TP } \\
\text { TS } \\
\text { Mean }\end{array}$ & $\begin{array}{l}3.28 \\
3.22 \\
2.96 \\
3.13 \\
3.14\end{array}$ & $\begin{array}{l}3.29 \\
2.99 \\
2.62 \\
3.40 \\
3.08\end{array}$ & $\begin{array}{l}3.52 \\
3.03 \\
2.16 \\
3.81 \\
3.13\end{array}$ & $\begin{array}{l}3.36 \\
3.08 \\
2.58 \\
3.45 \\
3.11\end{array}$ & $\begin{array}{l}\mathrm{T} \\
\mathrm{A} \\
\mathrm{A} \times \mathrm{T}\end{array}$ & 41 & $\begin{array}{l}0.141 \\
0.122 \\
0.244\end{array}$ & $\begin{array}{r}<0.001 \\
0.830 \\
<0.001\end{array}$ \\
\hline
\end{tabular}

${ }^{*}$ Each of these groups had one less determination of ApoB mRNA.

highly significant interaction however in faecal cholesterol excretion with a large difference in the quadratic regression between TS and TM + TP $(P<0.001)$.

Hepatic ApoB mRNA was influenced by type but not amount of dietary fat (Table 6) with the largest difference occurring between TM and TP $(P<0.001)$. There was also a significant difference in the regression of amount of TM or TP and ApoB mRNA $(P=0 \cdot 049)$. By contrast hepatic HMG-CoA reductase mRNA was not influenced by either type or amount of fat. There was, however, a significant effect when TS was compared with TM + TP $(P=0.051)$. A highly significant interaction between type and amount of fat on LDL-receptor mRNA was indicated. The largest difference was seen when the linear regressions for amount of fat were compared for TS and TM + TP $(P<0 \cdot 001)$.

\section{Discussion}

We have recently shown that, at low dietary cholesterol concentrations, different fatty acids have specific effects on lipoprotein metabolism in the hamster (Bennett et al. 1995a). In the current study these findings are extended to consider the dose-dependent effects of individual fatty acids. By isoenergetically replacing dietary carbohydrate with different purified fats, of known composition and structure, we have been able to increase the total amount of fat while making only very minor changes to the fatty acid composition.

Each of the saturated fats studied was fed in conjunction with TO to improve diet presentation and the absorption of the fats. It is therefore important to recognize that they may not only be having effects in their own right but also modulating any effect of oleic acid. Increasing the amount of TO alone in the diet increased hepatic cholesteryl ester concentrations and increased the plasma concentration of VLDL-cholesterol. This was associated with a decrease in the excretion of faecal cholesterol. Thus, it appears that, with increasing amounts of $\mathrm{TO}$ in the diet, the sequestration of cholesterol as cholesteryl ester in the liver may reduce biliary cholesterol excretion into the intestine and faeces and hence increase its secretion into the plasma as part of VLDL. When $50 \%$ of the TO in the test diets was replaced with TM then similar effects on plasma VLDL-cholesterol, hepatic cholesteryl ester and faecal cholesterol were seen as with TO alone. However, the magnitude of the changes was less and was consistent with the effect being due to the remaining $\mathrm{TO}$ in the diets. Thus, it appears that in this respect, myristic acid is neutral and does not influence the changes brought about by oleic acid. However, unlike TO alone, increasing amounts of TM in the diet increased plasma HDL-cholesterol concentrations. It is not clear what the mechanism of this effect is, but in monkeys fed on a low-cholesterol diet, coconut oil, which is rich in lauric and myristic acids, has been shown to decrease the fractional clearance rate of ApoA1, thus increasing plasma HDLcholesterol and ApoAl concentrations (Stucchi et al. 1991). It is also possible that TM may exert its effects on HDL-cholesterol through an inhibition of cholesteryl ester transfer protein (CETP) activity. Inhibition of CETP has been shown to increase HDL-cholesterol concentrations in hamsters (Zuckerman \& Evans, 1995). Furthermore, CETP appears to be regulated by diet, with cholesterol increasing activity (Stein et al. 1990; Kurushima et al. 1995) and oleic acid partially reversing this effect (Kurushima et al. 1995). 
It remains to be established what the effect of individual saturated fatty acids is, but an inhibition could produce the elevation in HDL-cholesterol seen in the present study.

Unlike TM, the TP diet did not lead to increases in VLDL-cholesterol, hepatic cholesteryl ester or faecal cholesterol. This suggests that dietary palmitic acid opposes some of the effects of oleic acid. TP-feeding did, however, markedly increase IDL-, LDL- and HDLcholesterol concentrations and was also associated with significant changes in hepatic gene expression. LDLreceptor mRNA concentrations were significantly decreased by TP. Down-regulation of hepatic LDL receptors may limit cholesterol availability in the liver and hence explain why hepatic cholesteryl ester concentrations do not increase in response to the oleic acid in the diet. The mechanism whereby palmitic acid reduces the concentration of mRNA coding the LDL receptor is not clear. It has been suggested (Woollett et al. 1992) that saturated fatty acids are poor substrates for acyl-CoA: cholesterol acyl transferase ( $E C 2.3 .1 .26)$ and that this leads to an increase in the putative metabolically active pool of unesterified cholesterol, resulting in sterol-mediated repression of the LDL receptor and HMG-CoA reductase genes. However, this does not explain why the effect on gene expression is specific to palmitic acid, particularly as this has been shown to be a relatively good substrate for acyl-CoA : cholesterol acyl transferase (Goodman et al. 1964).

The TP diet also increased hepatic ApoB gene expression, confirming our previous findings (Bennett et al. 1995a). We have also recently shown (Bennett et al. $1995 b$ ) that TP-feeding leads to a dose-dependent increase in hepatic microsomal triacylglycerol transfer protein (MTP) mRNA concentrations. Diet-induced changes in MTP mRNA in the hamster have previously been shown to be associated with changes in MTP protein concentration and transfer activity (Lin et al. 1994). The MTP is thought to be involved in the transfer of triacylglycerol from its site of synthesis, on the smooth endoplasmic reticulum, to the site of VLDL assembly. The increase in MTP mRNA associated with TP-feeding correlated positively with LDLcholesterol concentrations (Bennett et al. 1995b). Thus, concomitant increases in ApoB and MTP synthesis would be expected to result in increased VLDL secretion which, in the presence of reduced LDL receptor activity, could lead to the increase in LDL concentrations observed.

Like the TM-rich diet, TP also increased plasma HDLcholesterol concentration. Again the mechanism for this increase remains to be established.

It has been suggested for many years that stearic acid is not as hypercholesterolaemic as other long-chain saturates and as such was not included in several attempts to quantify the effects of saturated fats on plasma cholesterol, such as those by Keys et al. (1965) and Hegsted et al. (1965). More recently it has been included as a slightly hypocholesterolaemic effector in an attempt to update such equations ( $\mathrm{Yu}$ et al. 1995). The present study confirms that stearic acid has a neutral effect. None of the major lipoprotein fractions showed an increased cholesterol content with increasing amounts of TS in the diet and like palmitic acid, stearic acid appeared to inhibit any TO-related increase in hepatic cholesteryl ester or VLDL-cholesterol. No effect of TS was seen on hepatic gene expression. The reason for the apparently neutral effect of stearic acid has been the subject of considerable research. The digestion and absorption of stearic acid is less than shorter chain saturates but the magnitude of this effect is relatively small (Denke \& Grundy, 1991). We have shown (Bennett et al. 1995a) that, when fed in combination with TO, in excess of $95 \%$ of the stearic acid is absorbed and thus poor absorption is unlikely to explain the effects seen in the present study. Other workers have suggested that stearic acid may be extensively desaturated to oleic acid and that this is the reason for its effects (Denke \& Grundy, 1991). However, the extent to which this occurs is again unlikely to explain the current findings (Emken, 1994; Bruce \& Salter, 1996). Furthermore, if any significant desaturation occurred the characteristic oleate-induced accumulation of cholesteryl ester in the liver would have been expected in our experiments. We have shown that stearate is preferentially directed towards the synthesis of phospholipid rather than triacylglycerols in hamster hepatocytes (Bruce \& Salter, 1996) and fatty acid analysis of hepatic lipids in the present study showed that stearate was more readily incorporated into phospholipid than myristate or palmitate (results not shown). Such a change in membrane phospholipids may influence VLDL secretion, reducing the amount of cholesterol secreted through this route. It is also of note that TS-feeding was associated with an increase in faecal cholesterol excretion and no increase in hepatic cholesterol stores. This has also been reported by other workers (Imaizumi et al. 1993) and may be one explanation for the relative hypocholesterolaemic effect of stearic acid compared with other long chain saturates.

The present study shows that, even under dietary conditions where cholesterol intake is very low, saturated fatty acids exert differential, dose-dependent effects on cholesterol and lipoprotein metabolism. It is apparent that some of these effects are due to actions at the level of mRNA by changes in gene expression or message stability. The possibility that fatty acids themselves might have direct effects on gene expression (Amri et al. 1994; Gearing et al. 1994; Jump et al. 1994) opens a potentially new and exciting area of research.

\section{Acknowledgements}

We thank Lindsay White for her excellent technical assistance and Jim Craigon for his help and advice on the statistical analysis. This work was supported by the Ministry of Agriculture, Fisheries and Food (Project no. CSA 2047).

\section{References}

Amri E, Ailhaud G \& Grimaldi P-A (1994) Fatty acids as signal transducing molecules-involvement in the differentiation of preadipose to adipose cells. Journal of Lipid Research 35, 930937.

Bennett AJ, Billett MA, Salter AM, Mangiapane EH, Bruce JS, Anderton KL, Marenah CB, Lawson N \& White DA (1995a) Modulation of hepatic apolipoprotein B, 3-hydroxy-3-methylglutaryl-CoA reductase and low density lipoprotein receptor 
mRNA and plasma lipoprotein concentrations by defined dietary fats. Biochemical Journal 311, 167-173.

Bennett AJ, Billett MA, Salter AM \& White DA (1995b) Regulation of hamster hepatic microsomal triglyceride transfer protein mRNA levels by dietary fats. Biochemical and Biophysical Research Communications 212, 473-478.

Bonanome A \& Grundy SM (1988) Effect of dietary stearic acid on plasma cholesterol and lipoprotein levels. New England Journal of Medicine 318, 1244-1248.

Bruce JS \& Salter AM (1996) Metabolic fate of oleic acid, palmitic acid and stearic acid in cultured hamster hepatocytes. Biochemical Journal 316, 847-852.

Chomczynski P \& Sacchi N (1987) Single-step method of RNA isolation by acid guanidinium thiocyanate-phenol-chloroform extraction. Analytical Biochemistry 62, 156-159.

Denke MA \& Grundy SM (1991) Effects of fats high in stearic acid on lipid and lipoprotein concentrations in men. American Journal of Clinical Nutrition 54, 1036-1040.

Denke MA \& Grundy SM (1992) Comparison of effects of lauric acid and palmitic acid on plasma lipids. American Journal of Clinical Nutrition 56, 895-898.

Derr J, Kris-Etherton PM, Pearson TA \& Seligson FH (1993) The role of fatty acid saturation on plasma lipids, lipoproteins and apolipoproteins: II. The plasma total and low-density lipoprotein cholesterol response to individual fatty acids. Metabolism 42, 130-134.

Emken EA (1994) Metabolism of dietary stearic acid relative to other fatty acids in human subjects. American Journal of Clinical Nutrition 60, 1023S-1028S.

Gearing KL, Gottlicher M, Widmark E, Banner CD, Tollet P, Stromstedt M, Rafter JJ, Berge RK \& Gustafsson J-A (1994) Fatty acid activation of the peroxisome proliferator activated receptor, a member of the nuclear receptor gene superfamily. Journal of Nutrition 124, 1284S-1288S.

Goodman DS, Deykin D \& Shiratori T (1964) The formation of cholesterol esters with rat liver enzymes. Journal of Biological Chemistry 239, 1335-1345.

Grundy SM \& Denke MA (1990) Dietary influences on serum lipids. Journal of Lipid Research 31, 1149-1172.

Harley CB (1987) Hybridisation of oligo(dT) to RNA on nitrocellulose. Gene Analysis Techniques 4, 17-22.

Hegsted DM, McGandy RB, Myers ML \& Stare FJ (1965) Quantitative effects of dietary fat on serum cholesterol in man. American Journal of Clinical Nutrition 17, 281-295.

Imaizumi K, Abe K, Kuroiwa C \& Sugano M (1993) Fat containing stearic acid increases fecal neutral steroid excretion and catabolism of low density lipoproteins without affecting plasma cholesterol concentration in hamsters fed a cholesterol containing diet. Journal of Nutrition 123, 1693-1702.

Jump DB, Clarke SD, Thelen A \& Liimatta M (1994) Coordinate regulation of glycolytic and lipogenic gene expression by polyunsaturated fatty acids. Journal of Lipid Research 35, 1076-1084.
Keys A, Anderson JT \& Grande F (1965) Serum cholesterol response to changes in diet. IV. Particular saturated fatty acids in the diet. Metabolism 14, 776-787.

Kurushima H, Hayashi K, Toyota Y, Kambe M \& Kajiyama G (1995) Comparison of hypocholesterolemic effects induced by dietary linoleic acid and oleic acid in hamsters. Atherosclerosis 114, 213-221.

Lin MCM, Arbeeny C, Bergquist K, Kienzle B, Gordon DA \& Wetterau JR (1994) Cloning and regulation of hamster microsomal triglyceride transfer protein. Journal of Biological Chemistry 269, 29138-29145.

Mensink RP \& Katan MB (1992) Effects of dietary fatty acids on serum lipids and lipoproteins. A meta-analysis of 27 trials. Arteriosclerosis and Thrombosis 12, 911-919.

Stein Y, Dabach Y, Hollander G \& Stein O (1990) Cholesterol ester transfer activity in hamster plasma: increase by fat and cholesterol rich diets. Biochimica et Biophysica Acta 1042, 138-141.

Stucchi AF, Hennessy LK, Vespa DB, Weiner EJ, Osada J, Ordovas JM, Schaefer EJ \& Nicolosi RJ (1991) Effect of corn and coconut-oil containing diets with and without cholesterol on high density lipoprotein apoprotein A-I and hepatic apoprotein A-I mRNA levels in cebus monkeys. Arteriosclerosis and Thrombosis 11, 1719-1729.

Sundram K, Hayes KC \& Siru OH (1994) Dietary palmitic acid results in lower serum cholesterol than does a lauric-myristic acid combination in normolipemic humans. American Joumal of Clinical Nutrition 59, 841-846.

Tholstrup T, Marckmann P, Jespersen J \& Sandström B (1994a) Fat high in stearic acid favorably affects blood lipids and factor VII coagulant activity in comparison with fats high in palmitic acid or high in myristic and lauric acids. American Journal of Clinical Nutrition 59, 371-377.

Tholstrup T, Marckmann P, Jespersen J, Vessby B, Jart A \& Sandström B (1994b) Effect on blood lipids, coagulation, and fibrinolysis of a fat high in myristic acid and a fat high in palmitic acid. American Journal of Clinical Nutrition 60, 919-925.

Woollett LA, Spady DK \& Dietschy JM (1992) Saturated and unsaturated fatty acids independently regulate low density lipoprotein receptor activity and production rate. Journal of Lipid Research 33, 77-88.

Yu S, Derr J, Etherton TJ \& Kris-Etherton PM (1995) Plasma cholesterol-predictive equations demonstrate that stearic acid is neutral and monounsaturated fatty acids are hypocholesterolemic. American Journal of Clinical Nutrition 61 , 1129-1139.

Zock PL, de Vries JHM \& Katan MJ (1994) Impact of myristic acid versus palmitic acid on serum lipid and lipoprotein levels in healthy women and men. Arteriosclerosis and Thrombosis 14, 567-575.

Zuckerman SH \& Evans GF (1995) Cholesterol ester transfer protein inhibition in hypercholesterolemic hamsters - kinetics of apoprotein changes. Lipids 30, 307-311. 